\title{
Globalized Parochialism: Consequences of English as Lingua Franca in Philosophy of Science
}

\section{Gereon Wolters}

In recent decades, English has become the uncontestable lingua franca of philosophy of science and of most other areas of philosophy and of the humanities. To have a lingua franca produces enormous benefits for the entire scientific community. The price for those benefits, however, is paid almost exclusively by non-native speakers of English (NoNES). Section 1 identifies three asymmetries that individual NoNES researchers encounter: 'publication asymmetry', 'resources asymmetry', and 'team asymmetry'. Section 2 deals with 'globalized parochialism asymmetry': thanks to English being a lingua franca, a special ('parochial') perspective, mostly US and British, is being globalized and is replacing European topics and approaches. This has serious consequences for history of philosophy as well as for philosophical theory: thinkers of the past tend to be dealt with on the global level at best only if and insofar they are translated into English. Similarly, the theoretical agenda of globalized philosophy of science is set bymostly American-native English speakers (NES). This way, interesting and important topics and approaches from the European continent are marginalized or completely ignored in the world of globalized parochialism. In my view, the structural asymmetry and even unfairness on the global level between NES and NoNES cannot be eliminated but only attenuated.

\section{Language-related Asymmetries for Researchers}

Hyvät ystävät, tervetuloa symposiumiimme. Olemme nyt mitä luultavammin kielellisesti muiden ulottumattomissa. En itsekaän ymmärrä, mitä juuri sanon, mutta uskon tietäväni mitä puhun, sillä luotan kääntäjääni Katri Lahteen täysin. Kuvitellaanpa hetki, että suomen kieli olisi tieteenfilosofian Lingua Franca. Miltä meidän

Gereon Wolters is at the Department of Philosophy, University of Konstanz. Correspondence to: Fachbereich Philosophie, Universität Konstanz, Postfach 15, D 78457 Konstanz, Germany. E mail: gereon.wolters@uni konstanz.de 
kuvitteellinen suomen kielinen filosofinen maailmamme silloin näyttäisi? Väittäisin, että varsin erilaiselta kuin nykyinen filosofinen maailmamme.

This is a somewhat unusual start of a talk at a meeting, where everybody is supposed to speak English. I asked our Finnish friends to imagine for a moment that not English but Finnish was the lingua franca of science and philosophy. What would our philosophical world look like if we all had to speak and write Finnish in order to make ourselves understood? I think that philosophy, philosophy of science included, would look somewhat different, indeed, in that truly 'Finlandized' world. ${ }^{1}$

If we turn to the slightly more realistic scenario that Chinese was the lingua franca of science and philosophy, our philosophical world would most probably look even more different from the one we are used to.

Let me unequivocally state right at the outset: there is in the near future no alternative to English as lingua franca of science and philosophy. All attempts to ignore this are in my view waste of money, time, and energy and are doomed to failure.

English as lingua franca produces benefits for everyone. Like everything, however, those benefits come at a price, which native English speakers (NES) do not pay. ${ }^{2}$ Being a natural language in various countries, English as lingua franca creates fundamental asymmetries between NES and non-native English speakers (NoNES). ${ }^{3}$ The Belgian economist and philosopher, Philippe Van Parijs, in his important book, Linguistic Justice for Europe and for the World (Van Parijs 2011), speaks even of injustice.

Beyza Björkman has contested Van Parijs's asymmetry thesis in this journal. Björkman points to recent research suggesting that 'Academic English'-I like to call it English 'Academese'-is no-one's native language. It is rather 'a vehicular language for people of a range of first-language backgrounds' (Björkman 2012, 356). This argument is less than convincing for two reasons. First, there exist quite a number of academic languages, and there is quite a difference between learning a foreign 'Academese' and learning the academic language games in one's own language. Learning 'Academese' in one's own language is a comparatively effortless enterprisewe may observe it everyday with our students. Learning a foreign language, however, is quite another thing, as everybody knows who has tried it. Second, the difference between 'Academese' and the everyday language of one's own linguistic community seems to me less striking in Anglophone countries than in others. This holds at least for Germany, which may be a particular deterrent example. As a result, the asymmetry between NoNES and NES is not mitigated by the fact that in Anglophone countries, too, there is a difference between everyday language and 'Academese'. Rather, the opposite is true: NoNES have first to learn at school and/or later everyday English; second, at university they are socialized in their own 'Academese', which is later, third, followed by learning English 'Academese', while NES have only the problem of getting used to English 'Academese'.

The very interesting aspects of moral justice that Van Parijs is discussing cannot be dealt with here. Rather, I would like to concentrate on the fact that the price for English as lingua franca is paid, almost exclusively by NoNES. NES are 'free riding', as Van Parijs $(2011,51)$ puts it, and he calls for a 'fair arrangement', which 'need not', and in my view cannot, 'entail equal contributions to the cost of producing the joint benefit'. 
Here is a provisional list of basic language-related asymmetries between NES and NoNES. First, what I would like to call the publication asymmetry. It comes in two variants. The first is that publications in languages other than English are hardly taken notice of on an international level. I have made a random choice of two issues of Philosophy of Science, which many people consider the leading journal in the field. I have checked the first issues of volumes 80 (2013) and 81 (2014). They contain a total of 17 articles. Nine authors are based in the USA, four in the UK, and one each in Denmark, Germany, the Netherlands, and Spain. One finds 414 references. Exactly two, that is, fewer than $0.5 \%$, relate to work written in languages other than English: one in French, and the other in German.

One can explain this result by the fact that Philosophy of Science is the journal of the US-based Philosophy of Science Association, and that 13 out of 17 authors work at Anglophone institutions. To ignore publications in languages other than English seems quite natural for NES, since knowledge of foreign languages is rather limited not only among NES in general but also in particular among NES scholars. Those few scholars who actually know foreign languages hardly ever read and quote works written in those languages. But note that also the four NoNES authors in the issues of Philosophy of Science that I have checked quote no non-Anglophone work. Outside the Anglophone world, things might be similar. NoNES, as a rule, in addition to work in their own native language, take account only of publications written in English. I have checked various recent issues of the Germany-based journal Philosophia Naturalis, which still accepts articles in German as well as English. Here we find a roughly 50:50 ratio of references to works in German and English. Occasionally, but very rarely, even Italian or French titles appear. I suppose that things are not very different in other countries. One may say that, as a rule, also outside the Anglophone world work in languages other than English is taken notice of at most, only if there exist English translations. ${ }^{5}$ Occasionally I have even the impression that some NoNES have even given up reading philosophical texts in their own language.

The second variant of the publication asymmetry consists in a structural unfairness towards contributions in English coming from NoNES, because the editorial boards and the peer reviewers of the 'leading' journals in philosophy of science are overwhelmingly, in some cases even exclusively, Anglophone. This means that to a considerable degree Anglophone, mostly the USA, cultural traditions and fashions set the agenda of philosophy. Such traditions and fashions are, of course, legitimate. They should not prevail, however, because of the publication asymmetry. Unfortunately, the so-called European Reference Index for the Humanities (ERIH) is intensifying this type of unfairness. The ERIH has been developed by the European Science Foundation (ESF). Its latest (2nd) edition appeared in 2011. It contains sections both in 'philosophy' and in 'philosophy of science', and groups journals in three classes: National (NAT); International 1 (INT1); International 2 (INT2).

As to the acceptance criteria, we read: 'Any journal accepted in the ERIH list has to meet stringent benchmark standards: peer review of submissions, an active international editorial board ..., openness to new authors ... ? (ERIH 2011). 
Let us check the leading journals in our field against the criteria, 'peer review' and 'active international board'. As far as peer review is concerned, there is a vivid international discussion also in other domains, not only in philosophy, that has led to the finding that papers written by NoNES who come from institutions outside the NES world have a significantly smaller chance of being accepted. The reason for this is simple: my check of editorial boards and reviewers for Philosophy of Science, British Journal for the Philosophy of Science, and Biology and Philosophy in 1990, 2000, and 2010 shows that editorial boards and peer reviewers are mostly NES, and among NES mostly American (Wolters 2014, 287-289, where I give exact figures). NoNES representation is well below 10\%. At the British Journal for the Philosophy of Science even all members of the editorial board were NES. Now, those three journals checked are ranked INT1 in the ERIH, although they hardly meet the criterion of 'international editorial boards. ${ }^{6}$

The second asymmetry I would like to call the resources asymmetry. Playing in the Anglophone Champions League has become in most European ${ }^{7}$ countries a prerequisite of getting a job at a university. Only few scholars in the non-formal areas of the humanities are able to write papers or books in English without having them edited by a native speaker. This costs time and money, which is often paid from their own pocket, since only very few European universities finance such editing. An excellent positive example is, by the way, the host of the fourth biennial conference of the European Philosophy of Science Association, EPSA13, the University of Helsinki with its Language Services. Let me add another point. Some NoNES believe that they are just perfect in English. Empirical studies from cognitive neurology show that this is usually not the case for people who have learned English as a second language after the age of about five years. The deficits in the second language concern the lexicon, the understanding of complex grammatical structures, as well as the richness of associations of concepts (Rösler 2011, 2 and 7).

Finally, a third asymmetry, which I would like to call the team asymmetry. In soccer, it makes a great difference as to fame, income, and awareness level, whether one plays for Real Madrid or, say, for FC Konstanz. Similar things are true for philosophers. You are treated quite differently on the international level (e.g. invitations to conferences as invited speakers, to talks or summer schools) if you are member of a top team in the various university rankings. However, there is a great difference: the soccer ranking is rather objective. It depends on goals scored by the team, while the three university rankings of which I am aware ${ }^{8}$ are built largely or predominantly on criteria like peer evaluation and citation indices that to a large degree pretend objectivity. These two decisive criteria actually depend on publications in English in the 'leading' journals and publishing houses. Those NoNES who publish little or nothing in those places are unknown beyond the borders of their own linguistic community, and so are their respective universities. There is so far only one university ranking for philosophy (QS 2015). It shows the result to be expected according to team asymmetry: among the 50 'best' philosophy departments in the world, 36 are in Anglophone countries. The first non-Anglophone, Paris 1 -Sorbonne, is at position 21. 
One could say, of course, that university rankings are quite controversial among academics, and are not taken seriously in many ways by insiders. This might be true. It is also true, however, that there is hardly any European university that gets a good position in the ranking but fails to mention this as 'success' and proof of quality on their websites and in their Wikipedia entry. It is equally true that such rankings serve as a guide for fee-paying students from abroad, and creating the reputation of a university with politicians and the broader public.

\section{Globalized Parochialism and Cultural Asymmetries}

Given my personal experience and those of many others I have talked to, there is a widespread attitude of self-satisfaction in the Anglophone world, particularly in the USA and UK. I mean a habit to locate spontaneously in their part of the world everything worth thinking and speaking about. Only on further reflection may it come to mind that this might not be the case. Such habitually narrow scope one usually calls 'parochialism'. In contrast to traditional parochialism, which hardly ever crossed the borders of one's parish, the new Anglophone variety can claim to be globalized parochialism. ${ }^{9}$ To be sure, I do not see any malicious intent here in the sense that people consciously and explicitly might want to exclude the rest of the world. The rest of the world is simply taken little notice of. Things would hardly be different if Finnish, French, German, or any other language had become lingua franca. In my view, globalized Anglophone parochialism has its roots in a general human habit to watch and judge things through the lens of one's own culture. ${ }^{10}$ This universal habit has been reinforced in the case at hand by another component. Given both the general economic and military power (programmes to spy on our electronic communication included), and in their own view cultural supremacy, hardly any Americans and few British think that there might be positive developments worth acknowledging outside their own realm. Britain, the closest ally of the USA also in matters of spying on our electronic communication, has elevated a parochial attitude in 2004 to government policy: at age 14, British children in state schools are now allowed to drop foreign languages altogether. As was to be expected, youngsters gratefully accept this generous offer on a huge scale, and replace, for example, French by 'religious education' (Garner 2011; for an update, see Tickle 2013). ${ }^{11}$ To be sure, I know well to distinguish education- and culture-related decisions of governments from attitudes of scholars. In the end, however, such decisions will have, or have already had, a general cultural impact, including on scholarly attitudes. The message is: learning foreign languages is a waste of time for NES.

At this point, I would like to quote the gloomy summary of the linguist Jürgen Trabant, in order to give an impression about the general mood in some quarters: ${ }^{12}$

There exists not only an active colonialist treatment by Anglophone Wissenschaft ${ }^{13}$ of other scientific cultures (there are practically no quotes from other languages), but also young dynamic Wissenschaftler from those linguistic worlds are proud to be able to speak and read English so nicely. They look with contempt at the old 
Wissenschaftskulturen they originate from, i.e. they participate actively in their destruction. The gigantic destruction of Wissenschaftskulturen in other languages could be prevented by wissenschaftliche multilingualism. The prospects for this remain poor. (Trabant 2012,107$)^{14}$

The language-related asymmetries presented in section 1 (publication asymmetry, resources asymmetry, and team asymmetry) should have shown that NoNES are structurally at a disadvantage in the global market of ideas. What I would like to call the globalized parochialism asymmetry outweighs those asymmetries. The globalized parochialism asymmetry is a cultural phenomenon, and in the case at hand relates to philosophical content and topics, both in history of philosophy and in philosophical theory. It is interesting to note right at the outset that most of us NoNES are not aware of the influence that English as lingua franca and globalized parochialism have on philosophical content.

I start with history of philosophy. The example I am presenting has been of particular importance for me as my personal eye-opener. It is the entry, 'Logical Positivism', in Robert Audi's much-used The Cambridge Dictionary of Philosophy, second edition (Audi 1999). The author is Richard A. Fumerton, F. Wendell Miller Professor of Philosophy at the University of Iowa. Here is a quote from the first section:

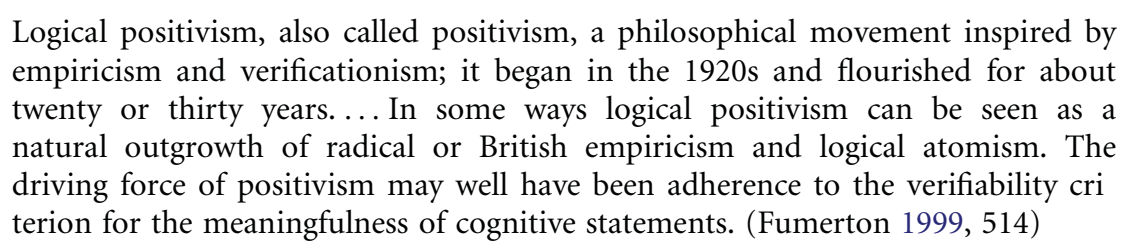

We learn from this that logical empiricism has exclusively British roots: as everybody will agree 'radical or British empiricism' is somehow essentially British, and for 'logical atomism' the Cambridge Dictionary unsurprisingly refers to 'Russell', who is correctly described as 'British philosopher, logician, social reformer, and man of letters, one of the founders of analytical philosophy' (Audi 1999, 699). I should add that the rest of Fumerton's article does not use any proper names or indexicals that could give a hint to possible historical influences that are not of a British origin. ${ }^{15}$ An innocent reader would conclude that 'logical positivism' is part of the British, and of no other, philosophical tradition. Well, I think even a vast a majority of NES, and everybody outside the Anglophone world knows better.

Nonetheless, I am afraid that the fact that Fumerton's article in two editions has not been corrected by the editor, Audi, or by any of the 28 'Editorial Advisors ${ }^{16}$ might not only be an expression of remarkable individual ignorance, combined with gratuitous Anglophone 'monoglot' self-confidence. Rather, it seems to be an indicator of what Anglophone 'globalization' has in store for philosophy in general and possibly for other parts of the humanities. ${ }^{17}$

Let me unequivocally state here a second point: the actual Anglophone preponderance in philosophy of science is in my view not only a consequence of English as lingua franca but is to a good deal well deserved as regards its achievements. What I would like to contest, however, is the degree in which NoNES are marginalized or simply ignored 
in a philosophical world of Anglophone domination. This domination we find also in other areas of academia.

James W. McAllister has observed that 'today, philosophy of science around the world, at least as practiced in English, is shaped largely by research priorities set in the United States'. He further rightly states: 'The pre-eminence of the US research agenda has fostered the view that there is a single global form of philosophy of science, which researchers in all countries practice' (McAllister 2008, 1).

Some might say that the European cultural submission to the Anglophone agenda is simply caused by the lack of interesting topics launched by European thinkers. This is not the case. There are, in my view, interesting topics and interesting philosophers in Europe that simply do not surface globally because their approaches do not fit the defaults of Globalized Parochialism. Years ago already, in this journal, McAllister wrote a programmatic editorial emphasizing that science is not culture independent, and that philosophy of science should also encompass 'the human sciences or Geisteswissenschaften as well as the natural and social sciences' (McAllister 2003, 5). Babich (2010), in her more comprehensive overview, brings up some important examples. Happily, the other articles of this symposium deal with some of them in detail. For example:

- Historical epistemology (Brenner 2015);

- The Erklären-Verstehen distinction in philosophy of the social sciences and of economics (Gonzalez 2015);

- The inclusion of typically European approaches into philosophy of science, like philosophy of historiography, for which NoNES use equivalents of 'science', or the significance of technology for science, and also the socio-political and moral implications of science (Radder 2015).

To these important topics that are completely ignored or strongly undervalued on the level of globalized parochialism, one might add more (Wolters 2014, 283ff.). An example is the so-called Erlangen Constructivism developed by Paul Lorenzen (1915-1994) and Wilhelm Kamlah (1905-1976), which has been expanded by Janich (2006) to an action theoretic, 'culturalistic' approach to science and philosophy of science. The culturalistic approach regards science as embedded in general culture and based on antecedent cultural practices. Philosophy of science consists accordingly in the rational reconstruction of forms and norms of these a priori elements.

Another example might be the very interesting pragmatic turn in philosophy of science made by Giulio Preti (1911-1972), which has been developed by his former student Paolo Parrini (1998) in new directions to a revival of positivism under the conditions of late-twentieth-century epistemology and philosophy of science. ${ }^{18}$

It is often difficult to say whether being ignored on the global level—philosophical quality provided-is due to the team asymmetry or to the globalized parochialism asymmetry. This holds not only for Parrini (University of Florence), but also for the Polish philosopher Leszek Nowak (1943-2009), who launched the contemporary debate on idealization and has made important contributions to it. He, nonetheless, 
is rarely quoted, although a substantial part of his work is published in English. He just seems to have had the wrong address: University of Poznań. Another example is the theory of truth approximation that has been developed by Ilkka Niiniluoto (1987), Theo Kuipers (2000), and others. Although there are publications in 'leading' Anglophone journals and although it is discussed among European philosophers of science, it has not been taken much notice of on the global level. I guess things would be different, if their addresses were NYU and Harvard instead of University of Helsinki and University of Groningen, respectively.

Such genuinely European approaches are sometimes not 'professional' in a narrow sense, ${ }^{19}$ that is, written by philosophers for philosophers, but rather address a general, educated public. Already Logical Empiricism in Vienna and Berlin regarded itself not only as a highly professional approach to questions of philosophy of science, but at the same time as an enlightenment movement directed at society at large. This cultural embedding of Logical Empiricism was lost for a great deal when Rudolph Carnap and friends fled to the USA. In the meantime it does not seem to have regained much strength. ${ }^{20}$ It occurs to me that this holds also to a certain degree for other Anglophone countries. Here is what the late Michael Dummett (1925-2011), an excellent analytic philosopher at Oxford, and himself in his fight against racism a notable counterexample to philosophical aloofness, testifies for the British case:

\begin{abstract}
Very few [in Britain] think that there's any call on them to be involved in any prac tical sense, and partly it's a tradition in this country, I must say, and not only amongst philosophers. Well, I was very impressed recently, a few years back. I and various other Italian philosophers, and other British ones as I recall it, we all pub lished articles in an Italian daily newspaper on philosophy. Now, that's unthinkable in this country, absolutely unthinkable! ... In France, and to a lesser extent in Italy, intellectuals generally and philosophers in particular are expected to make remarks on political and social questions. (Fara and Salles 2006, 10)
\end{abstract}

Unfortunately, the Anglophone perspective on European philosophy has been more and more internalized, even in non-Anglophone Europe: invited speakers at European conferences include almost always NES, often the majority is NES, and sometimes one looks in vain for at least one speaker of the NoNES. ${ }^{21}$ In Anglophone countries, however, not having NoNES as invited speakers is more the rule than the exception. My favourite example is from the mailing list Notizie filosofiche, 26 March 2012: for a conference at the Institute of Philosophy in London 'in collaboration with the University of East Anglia and supported by the Mind Association' on the topic 'Philosophical Insights', I count nine invited speakers, five from Britain and four from North America (Institute of Philosophy 2012). This selection suggests that the organizers did not expect any possible 'philosophical insights' coming from NoNES.

In a sense, the underrepresentation of Europeans on the globalized scene reminds me of the discrimination of female scholars that characterized philosophy for a long time. While the gender case has now reached a high level of awareness, many European colleagues have not even noticed the European case.

It is interesting, not to say depressing, to see how Europeans deepen the fundamental asymmetry by almost slavishly following the newest fashions that are proclaimed in 
the 'leading' journals in the field, and to ignore in their publications the work of their fellow NES. We Europeans, in my view, should rather work on building transnational European networks that take account of interesting developments on the continent without, of course, losing sight of and by taking part in what is happening on the globalized level. The ESF research networks chaired by Maria Carla Galavotti, ${ }^{22}$ the founding of the European Philosophy of Science Association, and the European Journal for Philosophy of Science are steps in the right direction. They have to be accompanied, however, by a change of our own attitudes and mentalities.

\section{Concluding Remarks}

I do not think that we NoNES can ever completely remove the asymmetry on the global scene, which is caused by English as lingua franca. But we could attenuate it considerably. I have given several hints to this effect on another occasion (Wolters 2014, 289ff.). Here I would like to mention some European deficiencies that contribute to our being junior partners at best in the world of globalized parochialism. These deficiencies have to do with severe shortcomings in the European university system. Apart from being underfinanced, the universities in most European countries suffer strongly from a recruiting system that is often clientelistic, nepotistic, and sometimes even simply corrupt. There are cases in which people gain a tenured job only shortly before retirement. American universities, with their open job market that offers young junior professors the prospect of tenure, might serve as model for us how to support independent and creative thinking.

Apart from these more organizational shortcomings of European universities, there might also be a cultural difference on the societal level. It is my anecdotal experience, at least, that in Anglophone countries families and schools put a greater emphasis on independent thinking and on open discussion than is the case in Europe. This attitude continues at the university level. While European philosophers seem to appreciate the model of the lone thinker, who rarely talks to colleagues and is hardly ever in his or her office, I have experienced open doors in Anglophone departments. In addition, continental departments sometimes are virtually nests of vipers, and not only in philosophy.

Given the structural unfairness that English as lingua franca brings with it for Europeans, I am afraid that we will have to work harder than our NES friends.

First of all, in order to become competitive on the global level.

Second, in order to create transnational European networks, in order to discuss topics and approaches that do not surface on the level of globalized parochialism.

And, finally, to contribute in the old European tradition to our national cultures. This we should do last but not least because our work depends on taxpayers' willingness to finance us.

\section{Acknowledgements}

I presented a previous version at this paper in the symposium, 'How Distinct Is European Philosophy of Science?', 4th Biennial Conference, European Philosophy of 
Science Association, Helsinki, August 2013. I would like to thank my friend Katri Lahti (Helsinki) for the Finnish translation and for the hard job of coaching my Finnish pronunciation. I thank the editor of this journal for helpful comments on an earlier draft.

\section{Notes}

[1] The term 'Finlandization' referred during the Cold War in a pejorative way to the wise Real politik of small Finland towards the neighbouring Soviet superpower. Finland, which had lost a war and part of its territory to the Soviet Union, in this way could preserve democracy and (to a very large degree) also sovereignty. Finlandization (Finnlandisierung) originated as a political catchword with US centric West German conservatives in the 1960s and 1970s, in order to fight the Ostpolitik of the social democrats, especially Willy Brandt, which aimed at improving the relationship with East Germany, the Soviet Union, and other 'socialist' countries.

[2] There might be a price for NES in the long run, though: see note 9.

[3] I take these acronyms from Clavero $(2010,552)$. In the rest of this article I shall refer only to European NoNES I like pronouncing it 'nones'. Taking account of the rest of the non Anglophone world is beyond the scope of the article.

[4] I should like to add that both references in languages other than English relate to historical texts.

[5] I am aware of the fact that this is not so in some philosophical sub disciplines, for example ancient philosophy.

[6] It is possible that the ERIH committee regards the fact that NES come from different countries as sufficient for 'internationality'. Such an interpretation of the internationality cri terion would, however, completely miss the point.

[7] In conformance with widespread use of 'Europe' in Britain itself, the UK is not regarded as 'European' in this article.

[8] These rankings are the UK based Times Higher Education (THE) ranking and Quacquarelli Symonds (QS) ranking, and the Shanghai based Academic Ranking of World Universities (ARWU).

[9] The misconception of their parochialism as universalism might be the price that NES are paying, mostly without being aware of it (Stekeler Weithofer 2011, esp. 77ff.).

[10] Note that also European NoNES are often and often rightly themselves accused of paro chial 'Eurocentrism' by non European NoNES.

[11] In December 2013, David Cameron, the British Prime Minister, recommended learning Chinese with the following argument: 'I want Britain linked up to the world's fast growing economies. And that includes our young people learning the languages to seal tomorrow's business deals.' This economy driven assessment of the value of language learn ing (and probably of the humanities in general) is quoted from Watt and Richard (2013).

[12] I do not share Trabant's impression of an 'active' colonialist treatment by NES because I cannot detect a corresponding intention.

[13] I have left the German Wissenschaft in this text because rendering it in English as 'science' would be misleading. Wissenschaft includes every discipline taught at universities, even theol ogy. Similar things (in most cases excluding theology) hold for the French science, the Italian scienza, the Dutch wetenschap, and other non English equivalents.

[14] 'Nicht nur gibt es eine aktive kolonialistische Behandlung anderer Wissenschaftskulturen durch die englischsprachige Wissenschaft (es wird so gut wie nichts Anderssprachiges mehr zitiert), sondern junge dynamische Wissenschaftler aus diesen anderen Sprachwelten sind stolz, dass sie so schon englisch reden und schreiben konnen. Sie verachten langst die alten Wissenschaftskulturen, denen sie entstammen, das heißt sie nehmen aktiv an der 
Zerstorung dieser Wissenschaftskulturen teil. Die gigantische Zerstorung von anderssprachi gen Wissenschaftskulturen konnte nur durch wissenschaftliche Mehrsprachigkeit verhindert werden. Die Aussichten dafur stehen schlecht.'

[15] In the respective article, the verifiability criterion of meaning is also traced back to British empiricism.

[16] All but one of the editorial advisors are NES.

[17] 'Translations into Chinese, Italian, Korean, Russian, and Spanish' are announced in the 1999 edition as 'forthcoming'. Happily enough for 'Logical Positivism', we read 15 years later on the Cambridge University Press website that those translations are still 'underway' (CUP 2014).

[18] Although Parrini's book is in English, it has been ignored almost completely. This shows that publishing in English even for excellent philosophical work is only a necessary but not a suf ficient condition for being recognized on the level of globalized parochialism. Those who read Italian may consult the presentation of Preti's work in Parrini and Scarantino (2004).

[19] On some consequences of so called professionalization in the case of philosophy of biology, see Callebaut (2013).

[20] I am well aware of exceptions, like the late Steven Toulmin, Philip Kitcher, Helen Longino, and a few others.

[21] A telling example of this conference policy is what was described in a circular in English as the 'First International Conference of the German Society for Philosophy of Science/Gesellschaft fur Wissenschaftsphilosophie (GWP) e.V.', which took place in March 2013. At this founding event of a German Society for Philosophy of Science that avoids the word 'German' in its very name, the circular mentions seven 'keynote speakers': four NES, one Greek, and, after all, two Germans.

[22] McAllister $(2008,2)$ correctly observes that the first of these networks did not appear 'to identify any specific European themes or approaches', a shortcoming that was slightly improved in the second.

\section{References}

Audi, Robert, ed. 1999. The Cambridge Dictionary of Philosophy. 2nd ed. Cambridge: Cambridge Uni versity Press.

Babich, Babette. 2010. “Towards a Critical Philosophy of Science: Continental Beginnings and Bug bears, Whigs, and Waterbears." International Studies in the Philosophy of Science 24: 343391.

Bjorkman, Beyza. 2012. "Review of Philippe Van Parijs, Linguistic Justice for Europe and for the World (Oxford: Oxford University Press, 2011).” International Studies in the Philosophy of Science 26: 354357.

Brenner, Anastasios. 2015. "Is There a Cultural Barrier Between Historical Epistemology and Ana lytic Philosophy of Science?" International Studies in the Philosophy of Science 29: 203216.

Callebaut, Werner. 2013. "Scholastic Temptations in the Philosophy of Biology." Biological Theory 8: 16.

Clavero, Miguel. 2010. “'Awkward Wording. Rephrase': Linguistic Injustice in Ecological Journals.” Trends in Ecology and Evolution 25: 552553.

CUP. 2014. "The Cambridge Dictionary of Philosophy." Cambridge University Press Catalogue. http://www.cambridge.org/us/academic/subjects/philosophy/philosophy general interest/ cambridge dictionary philosophy 2 nd edition.

ERIH. 2011. “European Reference Index for the Humanities.” http://www.esf.org/research areas/ humanities/erih european reference index for the humanities/erih foreword.html.

Fara, Rudolf, and Maurice Salles. 2006. "An Interview with Michael Dummett: From Analytical Phil osophy to Voting Analysis and Beyond." Social Choice and Welfare 27: 347364.

Fumerton, Richard A. 1999. "Logical Positivism." In The Cambridge Dictionary of Philosophy, edited by Robert Audi, 514 516. 2nd ed. Cambridge: Cambridge University Press. 
Garner, Richard. 2011. “The Language Crisis in British Schools.” Independent, 23 October. http:// www.independent.co.uk/news/education/education news/the language crisis in british schools 2061211.html.

Gonzalez, Wenceslao J. 2015. "From the Characterization of 'European Philosophy of Science' to the Case of Philosophy of the Social Sciences." International Studies in the Philosophy of Science 29: 167188.

Institute of Philosophy. 2012. "Philosophical Insights.” http://philosophy.sas.ac.uk/d/f/Philosophical Insights 21230612.pdf.

Janich, Peter. 2006. Kultur und Methode. Philosophie in einer wissenschaftlich gepragten Welt. Frank furt: Suhrkamp.

Kuipers, Theo. 2000. From Instrumentalism to Constructive Realism: On Some Relations between Con firmation, Empirical Progress, and Truth Approximation. Dordrecht: Kluwer.

McAllister, James W. 2003. "Editorial: The Integration of European Higher Education and the Nature of Philosophy." International Studies in the Philosophy of Science 17: 35.

McAllister, James W. 2008. "Editorial: Contours of a European Philosophy of Science." International Studies in the Philosophy of Science 22: 13.

Niiniluoto, Ilkka. 1987. Truthlikeness. Dordrecht: Reidel.

Parijs, Philippe Van. 2011. Linguistic Justice for Europe and for the World. Oxford: Oxford University Press. Parrini, Paolo. 1998. Knowledge and Reality: An Essay in Positive Philosophy. Dordrecht: Kluwer.

Parrini, Paolo, and Luca M. Scarantino, eds. 2004. Il pensiero filosofico di Giulio Preti. Milano: Guerini.

QS. 2015. "QS World University Rankings by Subject 2015 Philosophy." http://www.top universities.com/university rankings/university subject rankings/2015/philosophy.

Radder, Hans. 2015. "How Inclusive Is European Philosophy of Science?" International Studies in the Philosophy of Science 29: 149165.

Rosler, Frank. 2011. "Globalesisch: Fluch oder Segen? Einige Gedanken aus der Sicht der kognitiven Neurowissenschaft." In Welche Sprache(n) spricht die Wissenschaft?, edited by Jurgen Trabant, 135 146. Berlin: Berlin Brandenburgische Akademie der Wissenschaften.

Stekeler Weithofer, Pirmin. 2011. "Die Bedeutung der eigenen Sprache fur das Denken.” In Wissen schaffen Wissen kommunizieren. Wissenschaftssprachen in Geschichte und Gegenwart, edited by Wieland Eins, Helmut Gluck, and Sabine Pretscher, 73 84. Wiesbaden: Harrassowitz.

Tickle, Louise. 2013. "Languages in UK Schools: Where We Are vs. Where We Need to Be." Guardian, 13 May. http://www.theguardian.com/teacher network/2013/may/13/languages uk schools.

Trabant, Jurgen. 2012. “Uber die Lingua franca der Wissenschaft.” In Deutsch in der Wissenschaft. Ein politischer und wissenschaftlicher Diskurs, edited by Heinrich Oberreuther, Wilhelm Krull, Hans Joachim Meyer, and Konrad Ehlich, 101 107. Munchen: Olzog.

Watt, Nicholas, and Richard Adams. 2013. "David Cameron Urges British Students to Ditch French and Learn Mandarin." Guardian, 5 December. http://www.theguardian.com/politics/2013/ dec/05/david cameron ditch french learn mandarin china.

Wolters, Gereon. 2014. "Is There a European Philosophy of Science? A Wake up Call." In Philosophy of Science in Europe European Philosophy of Science and the Viennese Heritage, edited by Frie drich Stadler and Maria Carla Galavotti, 277 293. Dordrecht: Springer. 